Cite this: Dalton Trans., 2014, 43, 1736

Received 5th August 2013, Accepted 14th October 2013 DOI: $10.1039 / \mathrm{c} 3 \mathrm{dt} 52132 \mathrm{j}$ www.rsc.org/dalton

\section{Oxidative addition of disulfide/diselenide to group 10 metal(0) and in situ functionalization to form neutral thiasalen/selenasalen group 10 metal(॥) complexes $\uparrow$}

\author{
Pradip Kr. Dutta, Ashish K. Asatkar, Sanjio S. Zade* and Snigdha Panda* \\ Three components, one pot synthesis of thiasalen/selenasalen Ni(॥), Pd(॥) and Pt(॥) complexes, 14-19, by \\ the oxidative addition of $\mathrm{S}-\mathrm{S} / \mathrm{Se}$-Se bond of bis(o-formylphenyl)disulfide/-diselenide to $\mathrm{Ni}(0), \operatorname{Pd}(0)$ and \\ $\mathrm{Pt}(0)$ followed by in situ Schiff base formation with ethylenediamine is reported. S-S or Se-Se bonds \\ were cleaved and coordinated to the metal center as thiolate $\left(\mathrm{ArS}^{-}\right)$or selenolate $\left(\mathrm{ArSe}^{-}\right)$while the formal \\ oxidation state of metal centers was changed from ' 0 ' to ' +2 '. The disulfide/diselenide reacted with zero- \\ valent metals at room temperature to give only the monometallic complexes. All complexes (except Pd- \\ thiolate complex 15) were studied by single crystal X-ray crystallography and revealed the square planar \\ geometry around metal centers.
}

\section{Introduction}

Schiff base synthesized by the reaction of two equivalents of salicylaldehyde with one equivalent of ethylenediamine is known as 'salen' which provides potentially tetradentate chelating systems with a $\mathrm{N} 2 \mathrm{O} 2$ donor set. Metal complexes based on salen and its derivatives have drawn considerable attention in last few decades ${ }^{1}$ due to their applications in catalysis, biological studies, material science, molecular magnetism and sensory materials. ${ }^{2}$ As catalysts, such complexes have been successfully applied in many reactions such as oxidation, olefin epoxidation, cycloaddition and in asymmetric synthesis. ${ }^{3}$ Recently, salen-complexes were utilized to develop metal organic frameworks (MOFs) for their novel applications such as hydrogen gas storage and highly efficient catalysis. ${ }^{4}$ Sulfur and selenium analogues of salen (thiasalen and selenasalen with N2S2 and N2Se2 ligating sites) have attracted scant attention due to instability of thiol and selenol groups compared to the hydroxyl group of salen.

Oxidative addition of $\mathrm{E}-\mathrm{E}$ bonds $(\mathrm{E}=\mathrm{S}$ and $\mathrm{Se})$ of diorganodisulfides and -diselenides to low-valent transition metal complexes is a mild and efficient method to synthesize

Department of Chemical Sciences, Indian Institute of Science Education and Research, Kolkata, PO: BCKV campus main office, Mohanpur 741252, Nadia, West Bengal, India. E-mail: snigdha@iiserkol.ac.in, sanjiozade@iiserkol.ac.in $\dagger$ Electronic supplementary information (ESI) available: ${ }^{1} \mathrm{H},{ }^{13} \mathrm{C}$ and ${ }^{77} \mathrm{Se}$ spectra of complexes 14-19. CCDC 946622-996626. For ESI and crystallographic data in CIF or other electronic format see DOI: 10.1039/c3dt52132j chalcogenolato-metal complexes. ${ }^{5}$ The oxidative addition of diorganyl disulfides/diselenides to $\operatorname{Pd}(0)$ complexes, such as $\left[\operatorname{Pd}\left(\mathrm{PPh}_{3}\right)_{4}\right]$, was investigated for their addition to alkynes, which is an efficient single step method for the formation of two $\mathrm{C}-\mathrm{S} / \mathrm{Se}$ bonds in a stereoselective manner. ${ }^{6}$ Mechanistic studies on these reactions have been carried out using various types of disulfides/diselenides and alkynes from both the experimental and theoretical point of views. ${ }^{7}$ Yamamoto and Sekine have reported the oxidative addition of diaryl disulfides, ArS-SAr, with $\left[\mathrm{Ni}(\mathrm{COD})_{2}\right](\mathrm{COD}=1,5$-cyclooctadiene $)$ in the presence of basic ligands such as 2,2'-bipyridine, triethylphosphine. ${ }^{8}$ Oxidative addition of diaryl disulfides $(\mathrm{ArS})_{2}$ with $\left[\mathrm{Pd}\left(\mathrm{PPh}_{3}\right)_{4}\right]$ and $\left[\mathrm{Pt}\left(\mathrm{PPh}_{3}\right)_{4}\right]$ formed dimeric and monomeric complexes, respectively. ${ }^{9}$ The tendency of formation of dimeric complexes can be minimized by using electron withdrawing substituents on the aromatic rings of diaryl disulfide. This study also revealed that $\mathrm{Pt}(0)$ complexes have less tendency to form dimeric complexes compared to $\operatorname{Pd}(0)$ precursors. The oxidative addition of S-S bond of the ring systems to $\mathrm{Ni}(0)$, $\operatorname{Pd}(0)$ and $\operatorname{Pt}(0)$ to form $S, S$-dithiolate chelate complexes were also studied. ${ }^{10}$

Morley et al. ${ }^{11}$ have shown the formation of selenolate complexes via oxidative addition of $\mathrm{Ph}_{2} \mathrm{Se}_{2}$ and $\mathrm{Fc}_{2} \mathrm{Se}_{2}[\mathrm{Fc}=$ ferrocenyl] to $\operatorname{Pd}(0)$ and $\operatorname{Pt}(0)$. Laitinen et al. reported the oxidative addition of $\mathrm{Th}_{2} \mathrm{Se}_{2}$ and $\mathrm{Ph}_{2} \mathrm{Se}_{2}$ to $\mathrm{Pd}(0)$ and $\mathrm{Pt}(0) .{ }^{12}$ Reversible oxidative addition of Se-Se bonds to $\mathrm{Pt}(0)$ and $\mathrm{Pt}(\mathrm{II})$ precursors was observed by changing the ligand environment. ${ }^{13}$ However, oxidative addition of $\mathrm{Se}-\mathrm{Se}$ bond of diorganodiselenide to $\mathrm{Ni}(0)$ is not reported till the date. In addition to oxidative 
addition of $\mathrm{E}-\mathrm{E}$ bonds to group $10 \mathrm{M}(0)$ precursors, the cleavage of E-E bonds also have also been reported with Group 10 metals in higher oxidation states. ${ }^{14}$

Synthesis of ligands and complexes simultaneously by the formation of both carbon-heteroatom and heteroatom-metal bonds is a powerful technique in the preparation of metalloorganic self assemblies. ${ }^{15}$ The introduction of thiolates/selenolates into metal complexes directly by the oxidative addition of dichalcogenides are often complicated by the presence of dimeric/polynuclear and non-stoichiometric compounds, however, it can be avoided by using the chelating diselenide. ${ }^{5 a}$ Here we have used this approach to synthesize thiasalen and selenasalen complexes.

Earlier we reported the $\mathrm{Pd}(\mathrm{II})$ and $\mathrm{Pt}(\mathrm{II})$ complexes (5-11) which were prepared by the reactions of bis(alkyl)thiasalen (1) and bis(alkyl)selenasalen (2-4) ligands with $\mathrm{Pd}(\mathrm{II})$ and $\mathrm{Pt}(\mathrm{II})$ metal precursors. ${ }^{16}$ We have observed dealkylative complexation via nucleophilic substitution at $\mathrm{C}-\mathrm{E}$ bond $(\mathrm{E}=\mathrm{S}$, Se) where monocationic complexes act as a leaving groups. However, the attempts to prepare the analogous Ni(II) complexes were unsuccessful. In the synthesis of complexes 5-11, the two step process was applied; (i) synthesis and isolation of the ligand and then (ii) complexation with the metal precursors. Here we report the complete series of six neutral group $10 \mathrm{~d}^{8}$ metal complexes of thia/selenasalen ligands via oxidative addition of E-E bond of bis(orthoformyl)phenyl disulfide (12) and bis(orthoformyl)phenyl diselenide (13) to $\mathrm{Ni}(0), \operatorname{Pd}(0)$ and $\operatorname{Pt}(0)$ and subsequent in situ reaction of ethylene diamine. Thus it is a three component one pot reaction for facile synthesis of sulfur and selenium analogues of salen group 10 metal complexes. It is the first report on the synthesis of neutral thiasalen complexes of $\mathrm{Pd}$ and $\mathrm{Pt}$ and selenosalen complexes of Ni, Pd and Pt.

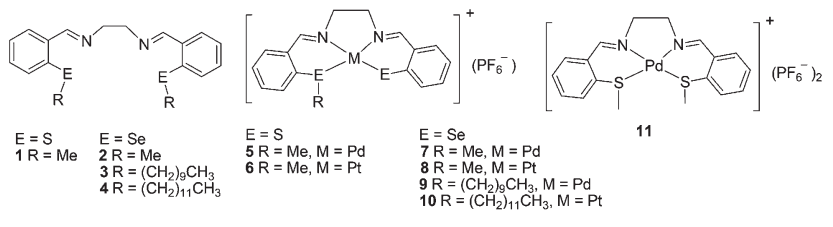

\section{Result and discussion}

\section{Synthesis of ligands}

The compounds $12^{17}$ and $13^{18}$ were synthesized according to the reported procedures. ${ }^{1} \mathrm{H}$ NMR spectrum of the ligand 12 showed a singlet at $\delta 10.23 \mathrm{ppm}$ for aldehyde protons whereas for ligand 13 showed a singlet at $\delta 10.17 \mathrm{ppm}$.

\section{Complexation of compound 12 and 13 with $\mathrm{Ni}(0), \operatorname{Pd}(0)$ and $\operatorname{Pt}(\mathbf{0})$}

Reactions of ligands 12 and 13 with $\mathrm{Ni}(0)$ ([Ni(COD $\left.\left.)_{2}\right]\right), \operatorname{Pd}(0)$ $\left(\left[\mathrm{Pd}\left(\mathrm{PPh}_{3}\right)_{4}\right]\right)$ and $\mathrm{Pt}(0)\left(\left[\mathrm{Pt}\left(\mathrm{PPh}_{3}\right)_{4}\right]\right)$ afforded six neutral thiolate and selenolate complexes 14-19 via oxidative addition of $\mathrm{E}-\mathrm{E}$ bond $(\mathrm{E}=\mathrm{S}, \mathrm{Se})$ to $\mathrm{Ni}(0), \operatorname{Pd}(0)$ and $\mathrm{Pt}(0)$ at room temperature (Scheme 1). As a result, S-S or Se-Se bonds were cleaved

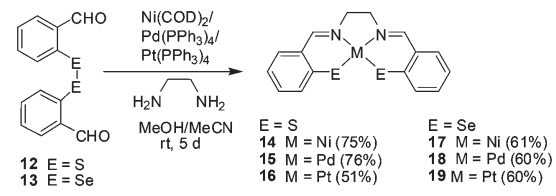

Scheme 1 Synthesis of complexes 14-19.

and coordinated to the metal center as thiolate $\left(\mathrm{ArS}^{-}\right)$or selenolate $\left(\mathrm{ArSe}^{-}\right)$while the formal oxidation state of metal center was changed from ' 0 ' to ' +2 '. The intermediate aldehyde complexes were used in situ as template for the preparation of desired Schiff base derivatives. Thus, it provides a one pot three component method for synthesis of the thiasalen and selenasalen $\mathrm{d}^{8}$ metal complexes by template synthesis using oxidative addition of bis(o-formylphenyl)disulfide/diselenide to $\mathrm{M}(0)(\mathrm{M}=\mathrm{Ni}, \mathrm{Pd}, \mathrm{Pt})$ precursors and imine bond formation by reaction with ethylenediamine. Template synthesis is a well established method for the one pot synthesis of Schiff-base complexes. In the template synthesis method a metal ion first coordinates with aldehyde to create the template for the reaction with amine to form metal ion coordinated Schiff-base. ${ }^{19}$ Thus, the concept of simultaneous use of oxidative addition and template synthesis is used here for one pot synthesis of thiasalen/selenasalen based metal complexes.

When one equivalent of ligand $\mathbf{1 2}$ was treated with one equivalent of $\left[\mathrm{Ni}(\mathrm{COD})_{2}\right],\left[\mathrm{Pd}\left(\mathrm{PPh}_{3}\right)_{4}\right]$ and $\left[\mathrm{Pt}\left(\mathrm{PPh}_{3}\right)_{4}\right]$ and one equivalent of 1,2-ethelenediamine, complexes 14, 15 and 16 were formed, respectively. All the three complexes are red in colour and stable in solid as well as in solution phase at ambient conditions. Complex 14 is soluble in $\mathrm{DCM}, \mathrm{CHCl}_{3}$, DMF and DMSO while complexes 15 and 16 are soluble in DMF and DMSO. Previously, Yamamura et al. ${ }^{20}$ reported the synthesis of complex 14 by the reaction of bis(2-(tert-butylthio)benzylidene)ethylenediamine with $\mathrm{NiCl}_{2} \cdot 6 \mathrm{H}_{2} \mathrm{O}$ with in situ cleavage of tert-butyl group. Goswami and Eichhorn ${ }^{15}$ reported the synthesis of $\mathbf{1 4}$ by the cleavage of disulfide bond in bis(o-formylphenyl)disulfide using $\left[\mathrm{Ni}(\mathrm{en})_{3}\right] \mathrm{Cl}_{2}$. In both the cases, $\mathrm{Ni}(\mathrm{II})$ ion was taken as metal source. Elemental analysis data of the compounds 14, 15 and 16 are consistent with the proposed formula and structures. ${ }^{1} \mathrm{H} /{ }^{13} \mathrm{C}$ NMR spectra of the complexes 14, 15 and 16 are in good agreement with the proposed structures. ${ }^{1} \mathrm{H}$ NMR spectra of the complexes 14, 15 and 16 showed a singlet at $\delta 8.59,8.72$ and $9.02 \mathrm{ppm}$ for azomethine protons, respectively. Complexes 14, 15 and 16 showed eight signals in the ${ }^{13} \mathrm{C}$ NMR spectra for eight different types of carbons indicating symmetrical nature of the complexes in solution. FT-IR spectra of the complexes 14, 15 and 16 displayed the characteristic $\nu_{(\mathrm{C}=\mathrm{N})}$ stretching frequencies at 1610, 1626 and $1617 \mathrm{~cm}^{-1}$, respectively, which were shifted to lower energy values compared to the $\nu_{(\mathrm{C}=\mathrm{O})}$ stretching frequency $\left(1691 \mathrm{~cm}^{-1}\right)$ of precursor 12 .

The selenium analogues 17, 18 and 19 were prepared by similar procedure using precursor bis(orthoformylphenyl) diselenide 13. Formulations of complexes 17-19 were supported by elemental analyses, however, elemental analysis for $\mathbf{1 8}$ was 
found to be slightly deviated from the calculated value of percentage of carbon. Color, stability and solubility of these complexes are quite similar to that of their sulfur analogues. ${ }^{1} \mathrm{H}$ NMR and ${ }^{13} \mathrm{C}$ NMR spectra of 17,18 and 19 showed symmetrical nature of these complexes. The characteristic imine protons were observed at $\delta 8.66,8.76$ and 9.09 ppm, respectively, in ${ }^{1} \mathrm{H}$ NMR spectra of 17,18 and $19 .{ }^{77}$ Se NMR of complexes 17, 18, 19 showed the single resonance at $\delta 354.9,393.7$, 318.9 ppm, respectively. In the FT-IR spectra of complexes 17, 18 and 19, peaks at 1609, 1622 and $1611 \mathrm{~cm}^{-1}$, respectively, were assigned to $\nu_{(\mathrm{C}=\mathrm{N})}$ stretching frequency. ESI-MS spectra of complexes 14 and 17 displayed the molecular ion peak at 356.37 and 452.1934 , respectively as $[\mathrm{M}+\mathrm{H}]^{+}$moieties, while the $\mathrm{Pd}(\mathrm{II})$ and $\mathrm{Pt}(\mathrm{II})$ complexes did not ionize in ESI mass spectrometer.

\section{Crystal structure study}

The molecular structures and supramolecular assemblies of 14, 16, 17, 18 and 19 have been determined by X-ray crystallography.

\section{Crystal structure of Ni-thiolate complex 14}

Complex 14 crystallizes in orthorhombic space group $P n a 2_{1}$ with the square planar geometry around metal center (Fig. 1). Space group, unit cell and bond lengths/angles are quite similar to those reported by Yamamura et al., ${ }^{20}$ while Goswami and Eichhorn ${ }^{15}$ reported the monoclinic space group $P 2_{1} / c$ with asymmetric unit containing two independent molecules and a dichloromethane molecule.

\section{Crystal structure of Pt-thiolate complex 16}

Complex 16 crystallizes in the monoclinic space group $P 2_{1} / c$ with a square planar geometry around the Pt(II) center (Fig. 2). The two Pt-S bonds are nearly equal and slightly shorter than

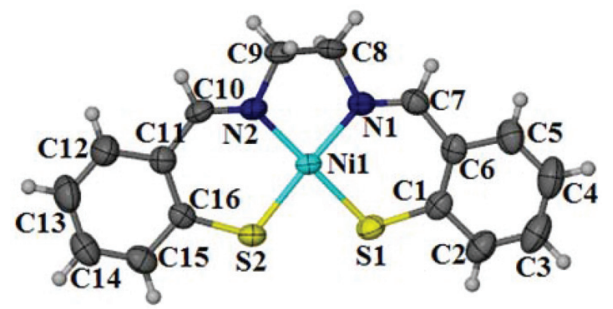

Fig. 1 ORTEP representation of nickel complex 14; thermal ellipsoids are drawn at $50 \%$ probability level.

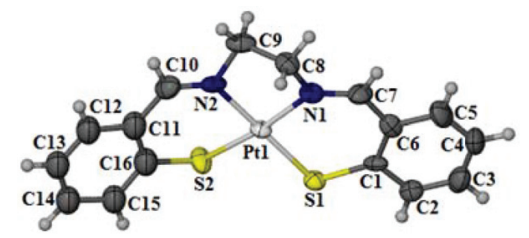

Fig. 2 ORTEP representation of platinum complex 16; thermal ellipsoids are drawn at $50 \%$ probability level.
Table 1 Selected bond lengths (Å) and angles $\left(^{\circ}\right)$ for 16

\begin{tabular}{llllr}
\hline S. no & \multicolumn{2}{l}{ Bond lengths $(\AA)$} & \multicolumn{2}{l}{ Bond angles $\left({ }^{\circ}\right)$} \\
\hline 1 & Pt1-S1 & $2.246(4)$ & S1-Pt1-S2 & $89.53(16)$ \\
2 & Pt1-S2 & $2.225(4)$ & N1-Pt1-N2 & $82.4(6)$ \\
3 & Pt1-N1 & $2.025(14)$ & S1-Pt1-N2 & $176.6(4)$ \\
4 & Pt1-N2 & $2.039(13)$ & S2-Pt1-N1 & $173.2(4)$ \\
5 & S1-C1 & $1.760(16)$ & S1-Pt1-N1 & $95.7(4)$ \\
6 & S2-C16 & $1.83(2)$ & S2-Pt1-N2 & $92.6(4)$
\end{tabular}

that in thioether-thiolate complex 12 (thioether Pt-S, 2.2614(7) $\AA$ and thiolate Pt-S, 2.2539(7) ̊), respectively. ${ }^{16 b}$ Selected bond lengths and bond angles are shown in Table 1. Crystal packing of complex 16 shows the formation of 2D sheet along $b c$ plane via $\mathrm{C}-\mathrm{H} \cdots \pi(\mathrm{H} 1 \mathrm{~A} \cdots \mathrm{C} 1-\mathrm{C} 6), \mathrm{H} 5 \cdots \mathrm{H} 14$ and $\mathrm{H} 1 \mathrm{~A} \cdots \mathrm{S} 1$ interactions (Fig. S1 $\dagger$ ). Intermolecular S1 $\cdots \mathrm{H} 2 \mathrm{~B}$ and $\mathrm{H} 5 \cdots \mathrm{H} 14$ interactions present in the crystal lattice construct the two dimensional sheet along ac plane (Fig. S2 $\dagger$ ).

\section{Crystal structure of Ni-selenolate complex 17}

The square planar geometry around Ni(II) center in complex 17 was confirmed by single crystal X-ray crystallography. Complex 17 crystallizes in triclinic space group $P \overline{1}$ with two asymmetric molecules in the unit cell (Fig. 3). The four Ni-Se bonds are nearly equal (average 2.263 $\AA$ ) and comparable to those reported for selenocarbamoyl benzamidine base Ni(II) complex (2.278 and $2.293 \AA)^{21}$ and 2-aminophenyl diselenolate based Ni(II) complex (2.295 $\AA^{22}$ which also have square planar geometry around the $\mathrm{Ni}(\mathrm{II})$ center with N2Se2 donor set. The average Ni-N bond distance is $1.894 \AA$. The various intermolecular nonbonding interactions including $\mathrm{CH} \cdots \pi$ (aromatic) interaction between the two molecules led to the formation of 1-D chain along $b$ axis (Fig. S3†). Selected bond lengths and bond angles are shown in Table 2.

\section{Crystal structure of Pd-selenolate complex 18}

Similar to complex 17, the crystal structure of complex 18 crystallizes in the triclinic space group $P \overline{1}$ with two molecules in the asymmetric unit $\left(Z=4, Z^{\prime}=2\right)$ and a square planar

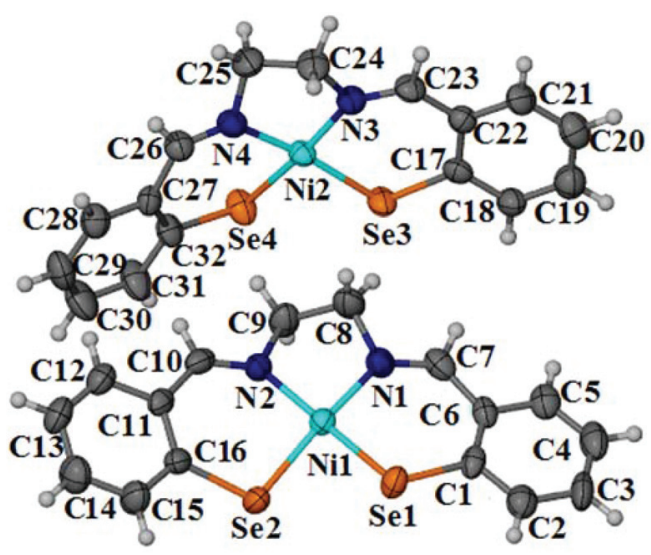

Fig. 3 ORTEP representation of platinum complex 17; thermal ellipsoids are drawn at $50 \%$ probability level. 
Table 2 Selected bond lengths ( $(\AA)$ and bond angles $\left(^{\circ}\right)$ for complex 17

\begin{tabular}{lllll}
\hline S. no & \multicolumn{3}{l}{ Bond lengths $(\AA)$} & \multicolumn{2}{l}{ Bond angles $\left({ }^{\circ}\right)$} \\
\hline 1 & Ni1-Se1 & $2.2576(13)$ & Se1-Ni1-Se2 & $83.60(5)$ \\
2 & Ni1-Se2 & $2.2578(13)$ & Se3-Ni2-Se4 & $84.03(4)$ \\
3 & Ni2-Se3 & $2.2860(13)$ & N1-Ni1-N2 & $86.9(2)$ \\
4 & Ni2-Se4 & $2.2518(13)$ & N3-Ni2-N4 & $86.52(19)$ \\
5 & Ni1-N1 & $1.897(4)$ & Se1-Ni1-N2 & $171.68(14)$ \\
6 & Ni1-N2 & $1.887(5)$ & Se2-Ni1-N1 & $171.53(14)$ \\
7 & Ni2-N3 & $1.896(5)$ & Se2-Ni1-N2 & $95.99(15)$ \\
8 & Ni2-N4 & $1.894(4)$ & Se1-Ni1-N1 & $94.73(15)$ \\
9 & Se1-C1 & $1.902(3)$ & Se3-Ni2-N3 & $93.10(13)$ \\
10 & Se2-C16 & $1.887(3)$ & Se3-Ni2-N4 & $172.87(15)$ \\
11 & Se3-C17 & $1.890(3)$ & Se4-Ni2-N3 & $172.33(16)$ \\
12 & Se4-C32 & $1.898(3)$ & Se4-Ni2-N4 & $97.20(14)$ \\
& & & &
\end{tabular}

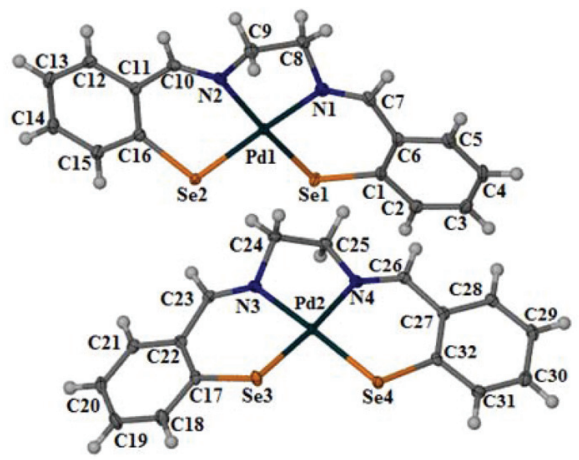

Fig. 4 ORTEP representation of palladium complex 18; thermal ellipsoids are drawn at $50 \%$ probability level.

geometry around the $\mathrm{Pd}(\mathrm{II})$ centers (Fig. 4). The average distance of four Pd-Se bonds is $2.366 \AA$ which is slightly shorter than Pd-Se bonds of nicotinoyl selenide based square planar Pd(II) complex (2.444 and 2.428 $\AA^{2} .^{23}$ The average of four Pd-N bond distances is $2.036 \AA$. Selected bond lengths and bond angles are shown in Table 3. Crystal packing of 18 shows the intermolecular $\mathrm{C}-\mathrm{H} \cdots \pi, \pi \cdots \pi$ and $\mathrm{Se} \cdots \mathrm{H}$ short contacts (Fig. S4†).

\section{Crystal structure of Pt-selenolate complex 19}

Complex 19 crystallizes in the triclinic space group $P \overline{1}$ with two molecules in the asymmetric unit $\left(Z=4, Z^{\prime}=2\right)$ and a square

Table 3 Selected bond lengths $(\AA \AA)$ and angles $\left({ }^{\circ}\right)$ for 18

\begin{tabular}{llllr}
\hline S. no & Bond lengths $(\AA)$ & \multicolumn{2}{l}{ Bond angles $(\circ)$} \\
\hline 1 & Pd1-Se1 & $2.3587(3)$ & Se1-Pd1-Se2 & $87.281(10)$ \\
2 & Pd1-Se2 & $2.3639(3)$ & Se3-Pd2-Se4 & $87.796(10)$ \\
3 & Pd2-Se3 & $2.3809(3)$ & N1-Pd1-N2 & $84.44(7)$ \\
4 & Pd2-Se4 & $2.3588(3)$ & N3-Pd2-N4 & $83.60(7)$ \\
5 & Pd1-N1 & $2.0328(18)$ & Se1-Pd1-N2 & $173.09(5)$ \\
6 & Pd1-N2 & $2.0358(18)$ & Se2-Pd1-N1 & $173.30(5)$ \\
7 & Pd2-N3 & $2.0344(19)$ & Se2-Pd1-N2 & $94.02(5)$ \\
8 & Pd2-N4 & $2.0390(17)$ & Se1-Pd1-N1 & $95.02(5)$ \\
9 & Se1-C1 & $1.893(2)$ & Se3-Pd2-N3 & $92.60(5)$ \\
10 & Se2-C16 & $1.899(2)$ & Se3-Pd2-N4 & $174.89(5)$ \\
11 & Se3-C17 & $1.898(2)$ & Se4-Pd2-N3 & $175.76(5)$ \\
12 & Se4-C32 & $1.895(2)$ & Se4-Pd2-N4 & $96.24(5)$
\end{tabular}

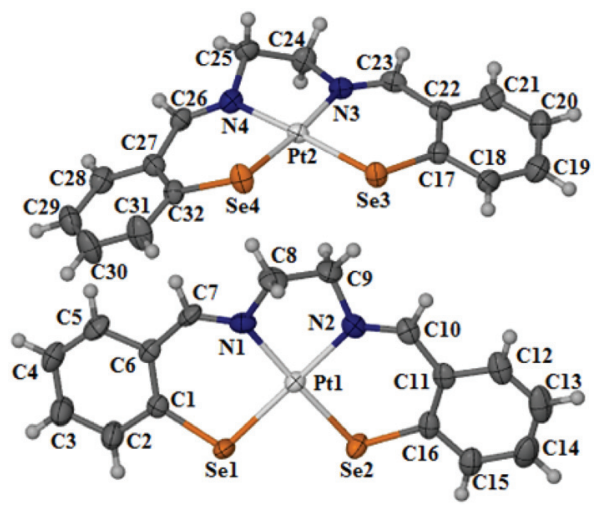

Fig. 5 ORTEP representation of palladium complex 19; thermal ellipsoids are drawn at $50 \%$ probability level.

Table 4 Selected bond lengths $(\AA)$ and angles $\left(^{\circ}\right)$ for 19

\begin{tabular}{lllll}
\hline S. no & \multicolumn{3}{l}{ Bond lengths $(\AA)$} & \multicolumn{2}{l}{ Bond angles $\left({ }^{\circ}\right)$} & \\
\hline 1 & Pt1-Se1 & $2.3641(7)$ & Se1-Pt1-Se2 & $87.08(3)$ \\
2 & Pt1-Se2 & $2.3731(7)$ & Se3-Pt2-Se4 & $87.58(2)$ \\
3 & Pt2-Se3 & $2.3866(7)$ & N1-Pt1-N2 & $83.3(2)$ \\
4 & Pt2-Se4 & $2.3672(7)$ & N3-Pt2-N4 & $83.2(2)$ \\
5 & Pt1-N1 & $2.017(5)$ & Se1-Pt1-N2 & $174.44(15)$ \\
6 & Pt1-N2 & $2.015(6)$ & Se2-Pt1-N1 & $174.43(15)$ \\
7 & Pt2-N3 & $2.027(5)$ & Se2-Pt1-N2 & $94.55(16)$ \\
8 & Pt2-N4 & $2.020(5)$ & Se1-Pt1-N1 & $95.53(17)$ \\
9 & Se1-C1 & $1.883(7)$ & Se3-Pt2-N3 & $93.28(15)$ \\
10 & Se2-C16 & $1.900(7)$ & Se3-Pt2-N4 & $174.95(15)$ \\
11 & Se3-C17 & $1.895(6)$ & Se4-Pt2-N3 & $175.96(15)$ \\
12 & Se4-C32 & $1.882(6)$ & Se4-Pt2-N4 & $96.20(15)$
\end{tabular}

planar geometry around the Pt(II) centre (Fig. 5). The four PtSe bonds are nearly equal and comparable to those in selenoether-selenolate complex 8 (selenoether Pt-Se, 2.3636(6) A and selenolate Pt-Se, 2.3583(6) ̊). ${ }^{16 a}$ The average Pt-N bond distance is $2.019 \AA$ A. Selected bond lengths and bond angles are shown in Table 4. Molecular packing of the complex is similar to that of nickel and palladium analogues.

Complete crystallographic data for complex 14, 16-19 are provided in Table 5 .

\section{Conclusion}

In summary, the reactions of ligands bis(o-formylphenyl)disulfide/-diselenide (12 and 13) with [Ni(COD) $\left.)_{2}\right],\left[\mathrm{Pd}\left(\mathrm{PPh}_{3}\right)_{4}\right]$ and $\left[\mathrm{Pt}\left(\mathrm{PPh}_{3}\right)_{4}\right]$ afforded six neutral square planar thiolate and selenolate complexes 14-19 via oxidative addition of $\mathrm{E}-\mathrm{E}$ bond $(\mathrm{E}=\mathrm{S}, \mathrm{Se})$ to $\mathrm{Ni}(0), \operatorname{Pd}(0)$ and $\mathrm{Pt}(0)$ followed by imine bond formation by reaction with ethylene diamine. Thus we developed three-component (group $10 \mathrm{M}(0)$ precursor, bis(o-formylphenyl)disulfide/-diselenide, and ethylene diamine), one-pot reaction for the synthesis of thiasalen and selenasalen group 10 metal complexes. We believe that the reaction can be extended to the various derivatives of complexes 14-19 by using substituted bis(o-formylphenyl)disulfide/-diselenide and 
Table 5 Crystallographic information of complex 14, 16, 17, 18 and 19

\begin{tabular}{|c|c|c|c|c|c|}
\hline Formula & $\mathrm{C}_{16} \mathrm{H}_{14} \mathrm{~N}_{2} \mathrm{NiS}_{2}$ & $\mathrm{C}_{16} \mathrm{H}_{14} \mathrm{~N}_{2} \mathrm{PtS}_{2}$ & $\mathrm{C}_{16} \mathrm{H}_{14} \mathrm{~N}_{2} \mathrm{NiSe}_{2}$ & $\mathrm{C}_{16} \mathrm{H}_{14} \mathrm{~N}_{2} \mathrm{PdSe}_{2}$ & $\mathrm{C}_{16} \mathrm{H}_{14} \mathrm{~N}_{2} \mathrm{PtSe}_{2}$ \\
\hline Crystal system & Orthorhombic & Monoclinic & Triclinic & Triclinic & Triclinic \\
\hline$a[\AA]$ & $8.9500(7)$ & $7.5651(9)$ & $10.398(6)$ & $10.3810(10)$ & $10.4940(12)$ \\
\hline$c[\AA]$ & $7.5123(7)$ & $26.820(3)$ & $12.955(7)$ & $12.7544(11)$ & $12.8887(16)$ \\
\hline$\alpha\left[0^{\circ}\right]$ & 90 & 90 & $71.269(13)$ & $72.987(2)$ & $72.482(2)$ \\
\hline$\beta[0]$ & 90 & $97.961(2)$ & $86.197(18)$ & $85.737(2)$ & $85.863(2)$ \\
\hline$\gamma\left[{ }^{\circ}\right]$ & 90 & 90 & $82.699(14)$ & $83.075(2)$ & $83.337(2)$ \\
\hline$\lambda[\AA]$ & 0.71073 & 0.71073 & 0.71073 & 0.71073 & 0.71073 \\
\hline$\rho_{\text {calcd }}\left[\mathrm{g} \mathrm{cm}^{-3}\right]$ & 1.555 & 2.059 & 1.959 & 2.185 & 2.506 \\
\hline$F[000]$ & 736 & 936 & 880 & 952 & 1080 \\
\hline$\mu\left[\mathrm{mm}^{-1}\right]$ & 1.538 & 9.070 & 6.023 & 6.021 & 13.684 \\
\hline$\theta[0]$ & $2.86-24.96$ & $2.57-24.97$ & $2.51-23.95$ & $2.54-25.04$ & $2.61-31.94$ \\
\hline Index ranges & $-10 \leq h \leq 10$ & $-8 \leq h \leq 9$ & $-11 \leq h \leq 12$ & $-12 \leq h \leq 12$ & $-7 \leq h \leq 13$ \\
\hline & $-26 \leq k \leq 26$ & $-5 \leq k \leq 9$ & $-14 \leq k \leq 14$ & $-14 \leq k \leq 14$ & $-15 \leq \bar{k} \leq 15$ \\
\hline$R_{\text {merge }}$ & 0.0257 & 0.0751 & 0.0731 & 0.0183 & 0.0410 \\
\hline Parameters & 190 & 160 & 331 & 379 & 379 \\
\hline GOF & 1.024 & 1.085 & 1.025 & 1.050 & 1.185 \\
\hline Total reflns & 11553 & 11915 & 21036 & 29289 & 24568 \\
\hline Unique reflns & 2681 & 2806 & 5597 & 5407 & 6805 \\
\hline Obsd reflns & 2445 & 2295 & 3920 & 5049 & 5752 \\
\hline CCDC no. & 946622 & 946625 & 946624 & 946623 & 946626 \\
\hline
\end{tabular}

various diamines. It is the first report on the synthesis of neutral thiasalen complexes of $\mathrm{Pd}$ and $\mathrm{Pt}$ and selenosalen complexes of Ni, Pd and Pt.

\section{Experimental section}

All reagents were purchased from Aldrich/Merck and used without further purification. Acetonitrile was distilled from $\mathrm{P}_{2} \mathrm{O}_{5}$ and kept over molecular sieves. ${ }^{1} \mathrm{H}$ and ${ }^{13} \mathrm{C}$ NMR spectra were recorded either on Bruker $500 \mathrm{MHz}$ or on JEOL-FT NMR-AL $400 \mathrm{MHz}$ spectrometer using DMSO- $d_{6}$ as solvent and tetramethylsilane $\left(\mathrm{SiMe}_{4}\right)$ as internal standards. ${ }^{77} \mathrm{Se}$ NMR spectra were recorded on Bruker $500 \mathrm{MHz}$ spectrometer using DMSO- $d_{6}$ as solvent. ${ }^{77}$ Se NMR chemical shifts are reported using $\mathrm{Ph}_{2} \mathrm{Se}_{2}$ as external standard with chemical shifts of $470 \mathrm{ppm}$ with respect to $\mathrm{Me}_{2} \mathrm{Se}$, thus the values are reported with respect to $\mathrm{Me}_{2} \mathrm{Se}$. IR spectra of the compounds have been recorded on a Perkin-Elmer spectrophotometer as $\mathrm{KBr}$ pellets. The mass spectra were recorded on a MICROMAX Q-TOFMICRO instrument. Melting points were measured using a digital melting point apparatus, SECOR INDIA.

\section{Crystal structure determination}

Single crystals of the compounds suitable for X-ray diffraction were grown from dimethyl formamide/dimethyl sulfoxide solution by diffusing diethyl ether vapors in a closed beaker. The crystals were carefully chosen using a stereomicroscope supported by a rotatable polarizing stage. The data were collected on Bruker's KAPPA APEX II CCD Duo with graphite monochromated Mo-K $\alpha$ radiation $(0.71073 \AA)$. The crystals were glued to a thin glass fibre using FOMBLIN immersion oil and mounted on the diffractometer. The intensity data were processed using Bruker's suite of data processing programs (SAINT), and absorption corrections were applied using SADABS. ${ }^{24}$ The crystal structure was solved by direct methods using SHELXS-97 and the data were refined by full matrix leastsquares refinement on $F^{2}$ with anisotropic displacement parameters for non-H atoms, using SHELXL-97. ${ }^{25}$ ORTEP diagrams are drawn from $\mathrm{X}$-seed version 2.0. ${ }^{26}$

\section{Thiasalen Ni(II) complex 14}

To a solution of bis(o-formylphenyl)disulfide 12 (74 mg, $0.27 \mathrm{mmol}$ ) in $10 \mathrm{~mL}$ dry methanol, [Ni(COD) $)_{2}$ (74 mg, $0.27 \mathrm{mmol}$ ) and ethylenediamine (16 mg, $0.27 \mathrm{mmol}$ ) were added at room temperature under nitrogen atmosphere. The reaction mixture was stirred for 5 days. Precipitate was filtered, washed thoroughly with methanol and dried in vacuum (yield: $72 \mathrm{mg}, 75 \%)$. Mp $272{ }^{\circ} \mathrm{C}(\mathrm{d}) .{ }^{1} \mathrm{H}$ NMR (400 MHz, DMSO- $\left.d_{6}\right): \delta$ 8.59 (s, 2H); $7.49(\mathrm{~m}, 4 \mathrm{H}) ; 7.22(\mathrm{~m}, 2 \mathrm{H}) ; 7.03(\mathrm{~m}, 2 \mathrm{H}), 3.72$ (s, $4 \mathrm{H}) \mathrm{ppm} .{ }^{13} \mathrm{C}$ NMR $\left(125 \mathrm{MHz}, \mathrm{DMSO}-d_{6}\right): \delta 163.77,144.70$, $134.96,130.41,129.69,129.36,121.65,61.26 \mathrm{ppm}$. IR $\nu_{\max }$ $\left(\mathrm{KBr}, \mathrm{cm}^{-1}\right)$ : $1610(\mathrm{C}=\mathrm{N})$. Anal. Calcd $(\%)$ for $\mathrm{C}_{16} \mathrm{H}_{14} \mathrm{~N}_{2} \mathrm{Ni} \mathrm{S}$ : C, 53.81; H, 3.95; N, 7.84. Found: C, 54.65; H, 4.02; N, 7.91\%. ESI-MS calcd for $\left\{\left(\mathrm{C}_{16} \mathrm{H}_{14} \mathrm{~N}_{2} \mathrm{NiS}_{2}+\mathrm{H}\right)^{+}\right\}, 357.0030$, found, 356.3700 .

\section{Thiasalen Pd(II) complex 15}

To a solution of bis(o-formylphenyl)disulfide 12 (100 mg, $0.36 \mathrm{mmol})$ in $10 \mathrm{~mL}$ dry acetonitrile, $\left[\mathrm{Pd}\left(\mathrm{PPh}_{3}\right)_{4}\right](410 \mathrm{mg}$, $0.36 \mathrm{mmol})$ and ethylenediamine $(26 \mathrm{mg}, 0.44 \mathrm{mmol})$ were 
added at room temperature under nitrogen atmosphere. The reaction mixture was stirred for 5 days. Precipitate was filtered, washed thoroughly with acetonitrile and dried in vacuum (yield: $117 \mathrm{mg}, 76 \%$ ). Mp $290{ }^{\circ} \mathrm{C}$ (d). ${ }^{1} \mathrm{H}$ NMR (400 MHz, DMSO- $\left.d_{6}\right): \delta 8.72(1 \mathrm{H}), 7.61-7.06(4 \mathrm{H}, \mathrm{Ar}-\mathrm{H}), 3.99(\mathrm{~s}, 2 \mathrm{H}) \mathrm{ppm}$. ${ }^{13} \mathrm{C}$ NMR (100 MHz, DMSO- $\left.d_{6}\right): \delta$ 161.80, 144.06, 136.93, 131.82, 130.87, 130.62, 121.91, $61.76 \mathrm{ppm}$. IR $\nu_{\max }\left(\mathrm{KBr}, \mathrm{cm}^{-1}\right)$ : $1626(\mathrm{C}=\mathrm{N})$. Anal. Calcd (\%) for $\mathrm{C}_{16} \mathrm{H}_{14} \mathrm{~N}_{2} \mathrm{PdS}_{2}$ : C, 47.47; $\mathrm{H}$, 3.49 ; N, 6.92. Found: C, 47.03; H, 3.29; N, 6.63\%.

\section{Thiasalen Pt(II) complex 16}

To a solution of bis(o-formylphenyl)disulfide 12 (100 mg, $0.36 \mathrm{mmol})$ in $10 \mathrm{~mL}$ dry acetonitrile, $\left[\mathrm{Pt}\left(\mathrm{PPh}_{3}\right)_{4}\right](450 \mathrm{mg}$, $0.36 \mathrm{mmol}$ ) and ethylenediamine (26 $\mathrm{mg}, 0.44 \mathrm{mmol}$ ) were added at room temperature under nitrogen atmosphere. The reaction mixture was stirred for 5 days. Precipitate was filtered, washed thoroughly with acetonitrile and dried in vacuum (yield: $92 \mathrm{mg}, 51 \%$ ). Mp $285{ }^{\circ} \mathrm{C}$ (d). ${ }^{1} \mathrm{H}$ NMR (400 MHz, DMSO$\left.d_{6}\right): \delta 9.02(1 \mathrm{H}), 7.67-7.04(4 \mathrm{H}, \mathrm{Ar}-\mathrm{H}), 3.94(\mathrm{~s}, 2 \mathrm{H}) \mathrm{ppm} .{ }^{13} \mathrm{C}$ NMR (100 MHz, DMSO- $d_{6}$ ): $\delta$ 157.20, 139.84, 135.89, 131.95, 131.08, 130.63, 122.03, $62.76 \mathrm{ppm}$. IR $\nu_{\max }\left(\mathrm{KBr}, \mathrm{cm}^{-1}\right): 1617$ $(\mathrm{C}=\mathrm{N})$. Anal. Calcd (\%) for $\mathrm{C}_{16} \mathrm{H}_{14} \mathrm{~N}_{2} \mathrm{PtS}_{2}$ : C, 38.94; H, 2.86; N, 5.68. Found: C, 38.76; H, 2.74; N, 5.31\%.

\section{Selenasalen Ni(II) complex 17}

To a solution of bis(o-formylphenyl) diselenide 13 (100 mg, $0.27 \mathrm{mmol}$ ) in $10 \mathrm{~mL}$ dry methanol, [Ni(COD) $)_{2}$ (74 mg, $0.27 \mathrm{mmol}$ ) and ethylene diamine $(17 \mathrm{mg}, 0.27 \mathrm{mmol}$ ) were added at room temperature under nitrogen atmosphere. The reaction mixture was stirred for 5 days. Precipitate was filtered, washed thoroughly with methanol and dried in vacuum (yield: $78 \mathrm{mg}, 61 \%) . \mathrm{Mp} 285{ }^{\circ} \mathrm{C}$ (d). ${ }^{1} \mathrm{H}$ NMR (500 MHz, DMSO- $\left.d_{6}\right)$ : $\delta 8.66(\mathrm{~s}, 1 \mathrm{H}) ; 7.68(\mathrm{~m}, 2 \mathrm{H}), 7.56(\mathrm{~m}, 2 \mathrm{H}), 7.19(\mathrm{~m}, 4 \mathrm{H}), 3.74(\mathrm{~s}$, $4 \mathrm{H})$ ppm. ${ }^{13} \mathrm{C}$ NMR $\left(125 \mathrm{MHz}, \mathrm{DMSO}-d_{6}\right): \delta 164.76,136.40$, 136.00, 132.72, 131.78, 130.22, 123.45, 62.04 ppm. ${ }^{77} \mathrm{Se}$ NMR (95 MHz, DMSO- $\left.d_{6}\right): \delta 354.9 \mathrm{ppm}$. IR $\nu_{\max }\left(\mathrm{KBr}, \mathrm{cm}^{-1}\right): 1609$ $(\mathrm{C}=\mathrm{N})$. Anal. Calcd (\%) for $\mathrm{C}_{16} \mathrm{H}_{14} \mathrm{~N}_{2} \mathrm{Se}_{2} \mathrm{Ni}$ : C, 42.62; H, 3.13; $\mathrm{N}, 6.21$. Found: C, 41.98; H, 2.95; N, 6.41\%. ESI-MS calcd for $\left\{\left(\mathrm{C}_{16} \mathrm{H}_{14} \mathrm{~N}_{2} \mathrm{NiSe}_{2}+\mathrm{H}\right)^{+}\right\}, 452.8919$, found, 452.1934 .

\section{Selenasalen Pd(II) complex 18}

To a solution of bis(o-formylphenyl) diselenide 13 (100 mg, $0.27 \mathrm{mmol})$ in $10 \mathrm{~mL}$ dry methanol, $\left[\mathrm{Pd}\left(\mathrm{PPh}_{3}\right)_{4}\right](310 \mathrm{mg}$, $0.27 \mathrm{mmol}$ ) and ethylenediamine (16 $\mathrm{mg}, 0.27 \mathrm{mmol})$ were added at room temperature under nitrogen atmosphere. The reaction mixture was stirred for 5 days. Precipitate was filtered, washed thoroughly with methanol and dried in vacuum (yield: $81 \mathrm{mg}, 60 \%) . \mathrm{Mp} 283{ }^{\circ} \mathrm{C}$ (d). ${ }^{1} \mathrm{H}$ NMR (400 MHz, DMSO- $\left.d_{6}\right)$ : $\delta 8.76(1 \mathrm{H}), 7.80-7.18(4 \mathrm{H}, \mathrm{Ar}-\mathrm{H}), 3.97$ (s, 2H) ppm. ${ }^{13} \mathrm{C} \mathrm{NMR}$ (125 MHz, DMSO- $d_{6}$ ): $\delta 162.69,137.70,134.70,133.66,132.84$, 131.46, 123.39, 62.45 ppm. ${ }^{77}$ Se NMR (95 MHz, DMSO- $d_{6}$ ): $\delta 393.7 \mathrm{ppm}$. IR $\nu_{\max }\left(\mathrm{KBr}, \mathrm{cm}^{-1}\right): 1622(\mathrm{C}=\mathrm{N})$. Anal. Calcd $(\%)$ for $\mathrm{C}_{16} \mathrm{H}_{14} \mathrm{~N}_{2} \mathrm{PdSe}_{2}$ : C, 38.54; H, 2.83; N, 5.62. Found: C, 40.79; $\mathrm{H}, 2.74 ; \mathrm{N}, 5.67 \%$.

\section{Selenasalen Pt(II) complex 19}

To a solution of bis (o-formylphenyl)diselenide 13 (100 mg, $0.27 \mathrm{mmol}$ ) in $10 \mathrm{~mL}$ dry methanol, [Pt $\left.\left(\mathrm{PPh}_{3}\right)_{4}\right]$ (340 mg, $0.27 \mathrm{mmol}$ ) and ethylenediamine (16 g, $0.27 \mathrm{mmol})$ were added at room temperature under nitrogen atmosphere. The reaction mixture was stirred for 5 days. Precipitate was filtered, washed thoroughly with methanol and dried in vacuum (yield: $96 \mathrm{mg}, 60 \%) . \mathrm{Mp} 297{ }^{\circ} \mathrm{C}$ (d). ${ }^{1} \mathrm{H}$ NMR (500 MHz, DMSO- $\left.d_{6}\right)$ : $\delta 9.09(1 \mathrm{H}), 7.80-7.16(4 \mathrm{H}, \mathrm{Ar}-\mathrm{H}), 3.91$ (s, 2H) ppm. ${ }^{13} \mathrm{C} \mathrm{NMR}$ (125 MHz, DMSO- $d_{6}$ ): $\delta$ 158.26, 137.01, 134.59, 132.71, 131.06, 123.67, 63.77 ppm. ${ }^{77} \mathrm{Se}$ NMR (95 MHz, DMSO- $\left.d_{6}\right)$ : $\delta 318.9 \mathrm{ppm}$. IR $\nu_{\max }\left(\mathrm{KBr}, \mathrm{cm}^{-1}\right): 1611(\mathrm{C}=\mathrm{N})$. Anal. Calcd $(\%)$ for $\mathrm{C}_{16} \mathrm{H}_{14} \mathrm{~N}_{2} \mathrm{PtSe}_{2}$ : C, 32.72; H, 2.40; N, 4.77. Found: C, 33.98; $\mathrm{H}, 2.26$; N, $5.05 \%$.

\section{Acknowledgements}

SP is thankful to Department of Science and Technology (DST), India for funding this work through Fast-Track project. PD is thankful to UGC for fellowship.

\section{References}

1 (a) S. Yamada, Coord. Chem. Rev., 1999, 190-192, 537-555; (b) C. J. Whiteoak, G. Salassa and A. W. Kleij, Chem. Soc. Rev., 2012, 41, 622-631; (c) J. Lewinski, J. Zachara, I. Justyniak and M. Dranka, Coord. Chem. Rev., 2005, 249, 1185-1199; (d) M. Kojima, H. Taguchi, M. Tsuchimoto and K. Nakajima, Chem. Soc. Rev., 2003, 237, 183-196.

2 (a) K. C. Gupta and A. K. Sutar, Coord. Chem. Rev., 2008, 252, 1420-1450; (b) A. Tzubery and E. Y. Tshuva, Inorg. Chem., 2011, 50, 7946-7948; (c) S. J. Wezenberg and A. W. Kleij, Angew. Chem., Int. Ed., 2008, 47, 2354-2364; (d) H. Miyasaka, A. Saitoh and S. Abe, Coord. Chem. Rev., 2007, 251, 2622-2664; (e) T. Glaser, Chem. Commun., 2011, 47, 116-130; $(f)$ L. D. Chen, D. Mandal, G. Pozzi, J. A. Gladysz and P. Bühlmann, J. Am. Chem. Soc., 2011, 133, 20869-20877.

3 (a) K. C. Gupta, A. K. Sutar and C.-C. Lin, Coord. Chem. Rev., 2009, 253, 1926-1946; (b) R. Drozdzak, B. Allaert, N. Ledoux, I. Dragutan, V. Dragutan and F. Verpoort, Coord. Chem. Rev., 2005, 249, 3055-3074; (c) C.-M. Che and J.-S. Huang, Coord. Chem. Rev., 2003, 242, 97-113.

4 (a) J.-R. Li, Y. Ma, M. C. McCarthy, J. Sculley, J. Yu, H.-K. Jeong, P. B. Balbuena and H.-C. Zhou, Coord. Chem. Rev., 2011, 255, 1791-1823; (b) R. J. Kuppler, D. J. Timmons, Q.-R. Fang, J.-R. Li, T. A. Makal, M. D. Young, D. Yuan, D. Zhao, W. Zhuang and H.-C. Zhou, Coord. Chem. Rev., 2009, 253, 3042-3066; (c) F. Song, C. Wang, J. M. Falkowski, L. Ma and W. Lin, J. Am. Chem. Soc., 2010, 132, 15390-15398; (d) Y.-M. Jeon, G. S. Armatas, J. Heo, M. G. Kanatzidis and C. A. Mirkin, Adv. Mater., 2008, 20, 2105-2110. 
5 (a) T. Chakraborty, K. Srivastava, H. B. Singh and R. J. Butcher, J. Organomet. Chem., 2011, 696, 2782-2788; (b) R. Kaur, S. C. Menon, S. Panda, H. B. Singh, R. P. Patel and R. J. Butcher, Organometallics, 2009, 28, 2363-2371; (c) E. Becker, K. Mereiter, R. Schmid and K. Kirchner, Organometallics, 2004, 23, 2876-2883; (d) S. H. Park, H. J. Gwon and K. B. Park, Chem. Lett., 2004, 33, 1278-1279; (e) W.-F. Liaw, C.-H. Hsieh, S.-M. Peng and G.-H. Lee, Inorg. Chim. Acta, 2002, 332, 153-159; $(f)$ R. Oilunkaniemi, R. S. Laitinen and M. Ahlgren, J. Organomet. Chem., 2001, 623, 168-175; $(g)$ C.-M. Lee, G.-Y. Lin, C.-H. Hsieh, C.-H. Hu, G.-H. Lee, S.-M. Peng and W.-F. Liaw, J. Chem. Soc., Dalton Trans., 1999, 2393-2398; (h) W.-F. Liaw, C.-H. Chen, G.-H. Lee and S.-M. Peng, Organometallics, 1998, 17, 2370-2372; (i) M. A. Aubart and R. G. Bergmann, J. Am. Chem. Soc., 1998, 120, 8755-8766; (j) L.-Y. Chia and W. R. McWhinnie, J. Organomet. Chem., 1978, 148, 165-170; (k) R. J. Haines, J. A. de Beer and R. Greatrex, J. Organomet. Chem., 1975, 85, 89-99.

6 (a) I. P. Beletskaya and V. P. Ananikov, Pure Appl. Chem., 2007, 79, 1041-1056; (b) I. Beletskaya and C. Moberg, Chem. Rev., 2006, 106, 2320-2354; (c) H. Kuniyasu, A. Ogawa, S.-I. Miyazaki, I. Ryu, N. Kambe and N. Sonoda, J. Am. Chem. Soc., 1991, 113, 9796-9803; (d) V. P. Ananikov, I. P. Beletskaya, G. G. Aleksandrov and I. L. Eremenko, Organometallics, 2003, 22, 1414-1421; (e) V. P. Ananikov, K. A. Gayduk, I. P. Beletskaya, V. N. Khrustalev and M. Y. Antipin, Eur. J. Inorg. Chem., 2009, 1149-1161; (f) V. P. Ananikov, M. A. Kabeshov, I. P. Beletskaya, V. N. Khrustalev and M. Y. Antipin, Organometallics, 2005, 24, 1275-1283.

7 (a) V. P. Ananikov and I. P. Beletskaya, Russ. Chem. Bull., 2004, 53, 561-565; (b) V. P. Ananikov, M. A. Kabeshov, I. P. Beletskaya, G. G. Aleksandrov and I. L. Eremenko, J. Organomet. Chem., 2003, 687, 451-461; (c) V. P. Ananikov, I. P. Beletskaya, G. G. Aleksandrov and I. L. Eremenko, Organometallics, 2003, 22, 1414-1421; (d) A. Ogawa, J. Organomet. Chem., 2000, 611, 463-474; (e) J. M. Gonzales, D. G. Musaev and K. Morokuma, Organometallics, 2005, 24, 4908-4914.

8 T. Yamamoto and Y. Sekine, Inorg. Chim. Acta, 1984, 83, 47-53.

9 R. Zanella, R. Ros and M. Graziani, Inorg. Chem., 1973, 12, 2736-2738.

10 (a) K. Kudoh, T. Okamoto and S. Yamaguchi, Organometallics, 2006, 25, 2374-2377; (b) H.-D. Stachel, B. Zimmer, E. Eckl, K. Semmlinger, W. Weigand, R. Wuensch and P. Mayer, Helv. Chim. Acta, 2005, 88, 1208-1220; (c) N. Kano, S. Kusaka and T. Kawashima, Dalton Trans., 2010, 39, 456-460; (d) U. Siemeling, F. Bretthauer and C. Bruhn, J. Organomet. Chem., 2010, 695, 626-629; (e) H. Petzold, T. Weisheit, S. Braeutigam, H. Goerls, G. Mloston and W. Weigand, Eur. J. Inorg. Chem., 2010, 3636-3641; $(f)$ B. Khalili Najafabadi, M. Hesari, M. S. Workentin and J. F. Corrigan, J. Organomet. Chem., 2012, 703, 16-24; $(g)$ T. Weisheit, A. Kriltz, H. Goerls,
G. Mloston, W. Imhof and W. Weigand, Chem.-Asian J., 2012, 7, 1383-1393; (h) A. Ishii, S. Kashiura, Y. Hayashi and W. Weigand, Chem.-Eur. J., 2007, 13, 4326-4333.

11 C. P. Morley, C. A. Webster and M. D. Vaira, J. Organomet. Chem., 2006, 691, 4244-4249.

12 (a) R. Oilunkaniemi, R. S. Laitinen and M. Ahlgrén, J. Organomet. Chem., 1999, 587, 200-206; (b) R. Oilunkaniemi, R. S. Laitinen and M. Ahlgrén, J. Organomet. Chem., 2001, 623, 168-175.

13 (a) A. Panunzi, G. Roviello and F. Ruffo, Organometallics, 2002, 21, 3503-3505; (b) V. G. Albano, M. Monari, I. Orabona, A. Panunzi and F. Ruffo, J. Am. Chem. Soc., 2001, 123, 4352-4353.

14 (a) K. J. Bonnington, M. C. Jennings and R. J. Puddephatt, Organometallics, 2008, 27, 6521-6530; (b) M. S. McCready and R. J. Puddephatt, Inorg. Chem. Commun., 2011, 14, 210-212; (c) A. J. Canty, H. Jin, B. W. Skelton and A. H. White, Inorg. Chem., 1998, 37, 3975-3981; (d) T. Schaub, M. Backes, O. Plietzsch and U. Radius, Dalton Trans., 2009, 7071-7079; (e) J. R. Zimmerman, B. W. Smucker, R. P. Dain, M. J. Van Stipdonk and D. M. Eichhorn, Inorg. Chim. Acta, 2011, 373, 54-61; (f) A. J. Canty, M. C. Denney, J. Patel, H. Sun, B. W. Skelton and A. H. White, J. Organomet. Chem., 2004, 689, 672-677; (g) C.-H. Hsieh, I.-J. Hsu, C.-M. Lee, S.-C. Ke, T.-Y. Wang, G.-H. Lee, Y. Wang, J.-M. Chen, J.-F. Lee and W.-F. Liaw, Inorg. Chem., 2003, 42, 3925-3933; (h) R. Kaur, S. C. Menon, S. Panda, H. B. Singh, R. P. Patel and R. J. Butcher, Organometallics, 2009, 28, 2363-2371; (i) S. Dey, V. K. Jain, B. Varghese, T. Schurr, M. Niemeyer, W. Kaim and R. J. Butcher, Inorg. Chim. Acta, 2006, 359, 1449-1457; (j) S. Dey, V. K. Jain, S. Chaudhury, A. Knoedler, F. Lissner and W. Kaim, J. Chem. Soc., Dalton Trans., 2001, 723-728.

15 N. Goswami and D. M. Eichhorn, Inorg. Chim. Acta, 2000, 303, 271-276.

16 (a) S. Panda, G. R. Ramakrishna, C. M. Reddy and S. S. Zade, Dalton Trans., 2011, 40, 6684-6690; (b) P. K. Dutta, S. Panda, G. R. Ramakrishna, C. M. Reddy and S. S. Zade, Dalton Trans., 2013, 42, 476-483.

17 M. Martinek, M. Korf and J. Srogl, Chem. Commun., 2010, 46, 4387-4389.

18 S. Panda, S. S. Zade, H. B. Singh and G. Wolmershauser, J. Organomet. Chem., 2005, 690, 3142-3148.

19 (a) P. A. Vigato, V. Peruzzo and S. Tamburini, Coord. Chem. Rev., 2012, 256, 953-1114; (b) A. D. Garnovskii, A. L. Nivorozhkin and V. I. Minkin, Coord. Chem. Rev., 1993, 126, 1-69; (c) D. J. Sheeran and K. B. Mertes, J. Am. Chem. Soc., 1990, 112, 1055-1061.

20 T. Yamamura, M. Tadokoro, K. Tanaka and R. Kuroda, Bull. Chem. Soc. Jpn., 1993, 66, 1984-1990.

21 C.-H. Hsieh, I-.J. Hsu, C.-M. Lee, S.-C. Ke, T.-Y. Wang, G.-H. Lee, Y. Wang, J.-M. Chen, J.-F. Lee and W.-F. Liaw, Inorg. Chem., 2003, 42, 3925-3933.

22 A. Bredenkamp, X. Zeng and F. Mohr, Polyhedron, 2012, 33, 107-113. 
23 R. S. Chauhan, C. P. Prabhu, P. P. Phadnis, G. Kedarnath, J. A. Golen, A. L. Rheingold and V. K. Jain, J. Organomet. Chem., 2013, 723, 163-170.

24 Bruker, SADABS V2008-1, Bruker AXS, Madison, WI, USA, 2008.
25 G. M. Sheldrick, Acta Crystallogr., Sect. A: Fundam. Crystallogr., 2008, 64, 112-122.

26 L. J. Barbour, X-Seed, Graphical Interface to SHELX-97 and POV-Ray, University of Missouri, Columbia, MO, 1999. 